SHORT COMMUNICATION

\title{
Germination, harvesting stage, antioxidant activity and consumer acceptance of ten microgreens
}

\author{
Gayathree I. Senevirathne ${ }^{1}$, N. S. Gama-Arachchige ${ }^{1,2}, *$ and Anjani M. Karunaratne ${ }^{1,2}$ \\ ${ }^{1}$ Department of Botany, Faculty of Science, University of Peradeniya, Peradeniya, Sri Lanka \\ ${ }^{2}$ Postgraduate Institute of Science, University of Peradeniya, Peradeniya, Sri Lanka
}

Received: 17/10/2018; Accepted: 28/01/2019

\begin{abstract}
Microgreens which are tender immature seedlings of vegetables and herbs are known for their health beneficial effects. The concept of microgreens is generally less popular in many countries including Sri Lanka. Ten species were tested to obtain data on seed germination, height gain, leaf area expansion, and consumer acceptance. Of these, three species of which the seeds are commonly consumed in Sri Lanka were analyzed for antioxidant activities as seeds, sprouts, and microgreens. Seed germination of most of the species was $>75 \%$ with the time taken to reach $75 \%$ germination $\left(\mathrm{G}_{75}\right)$ varying from 1 to $>14$ days. A strong positive correlation between seedling and leaf area was observed $\left(R^{2}=0.8\right)$. Lettuce and carrot were found to be the most preferred microgreens followed by green peas, red amaranth and finger millet. For the three selected species where respective seeds, sprouts, and microgreens were compared, higher antioxidant activities were recorded in finger millet seeds and sesame microgreens; $\mathrm{IC}_{50} 697$ $\mu \mathrm{g} / \mathrm{mL}$ and $\mathrm{IC}_{50} 772 \mu \mathrm{g} / \mathrm{mL}$ respectively with the latter recording a high total phenol content ( $4873 \mathrm{mg} / 100 \mathrm{~g}$ dry weight). Green pea microgreens showed higher total phenol content than its seeds and sprouts (1871 mg/100 g dry weight). The information generated will be of value to introduce microgreens to countries where consumers are unfamiliar with this product.
\end{abstract}

Keywords: Antioxidants, consumer acceptance, harvesting stage, microgreens, seed germination.

\section{INTRODUCTION}

Microgreens have gained popularity worldwide for their micronutrient complement and health promoting phytochemicals (Xiao et al., 2016). Their bioactives include higher levels of antioxidant compounds such as polyphenols, $\beta$ carotene, and ascorbic acid, than their mature plants thus qualifying as functional foods (Xiao et al., 2012; Mir et al., 2017). With non-communicable diseases causing major health concerns worldwide (WHO, 2017), seeking for functional foods has accelerated in recent years.

In the absence of a legal definition, the terms 'microgreens' and 'baby greens' are used to distinguish these miniature plants (Treadwell et al., 2010). A widely accepted definition of microgreens is "Tender immature greens produced from seeds of vegetables and herbs having fully developed cotyledons with or without the emergence of a rudimentary pair of first true leaves" (Xiao et al.,
2012). Microgreens are larger than sprouts, but are smaller than baby greens and therefore their harvesting stages are also in between those two stages (Xiao et al., 2012; Ebert, 2012). Baby greens are the oldest (usually $7-10 \mathrm{~cm}$ tall) and microgreens (usually $2.5-6 \mathrm{~cm}$ tall) are more differentiated than sprouts (Treadwell et al., 2010; Xiao et al., 2012).

There is a scarcity of information on types of seeds suitable to be developed as microgreens. The definition of Xiao et al. (2012) suggests the necessity to use epigeal germination seeds. However, it would be informative to know how hypogeal germination plants would contribute as functional foods. As ideal conditions for seed germination varies (Baskin and Baskin, 2014), meeting growth requirements without elaborate equipment is helpful for commercial microgreen growers. This preliminary study seeks direction on the introduction of microgreens.

\section{MATERIALS AND METHODS}

\section{Seed sources and experimental conditions}

Seeds used for planting and for consumption were obtained from retailers in Kandy, Sri Lanka. Seeds for cultivation were pre-treated with fungicides. Throughout, the parameters defined by Xiao et al. (2012) were used as the specified standards for microgreens.

\section{Germination determined in light/dark treatments and in total darkness}

Seeds were germinated in an incubator (model: MQC 4508P) providing a daily $12 \mathrm{~h} / 12 \mathrm{~h}$ light/dark period (temperature $25{ }^{\circ} \mathrm{C}$, light phase photon irradiance was approx. $115 \mu \mathrm{mol}$ photons $\mathrm{m}^{-2} \mathrm{~s}^{-1}, 400-700 \mathrm{~nm}$, supplied by cool white fluorescent tubes). Surface sterilized seeds ( $1 \%$ sodium hypochlorite) were germinated in petri-dishes lined with moist paper towels. When testing the effect of total darkness (24 h), petri-dishes were covered with aluminum foil. For light/dark treatment, the number of germinated seeds was counted daily for 14 days and for total darkness, counting was done after 7 and 14 days (separate petridishes). 


\section{Growing microgreens}

Microgreens were grown in perforated plastic trays (20x15 $\mathrm{cm})$ filled with autoclaved $\left(120{ }^{\circ} \mathrm{C}, 120 \mathrm{~Pa}\right.$ pressure, 90 min.) mixture of commercially processed compost and coir dust (1:1/v:v). Until cotyledons developed, overhead irrigation was done and after hypocotyls emerged, bottom irrigation (300 mL per day) was done (Kopsell et al., 2012). Dark germinating seeds were covered with a sprinkling of the growth medium sufficient to prevent exposure to light. The trays were kept in the same incubator.

\section{Harvesting stage and correlation between seedling height and leaf area}

The height and leaf area (digital photographs with Image $\mathrm{J}$ software (ver. 1.47) were measured every two days (from day 2 to 14 depending on the species). Leaf areas were determined after cotyledons (epigeal germination) or true leaves (hypogeal germination) appeared until they exceeded the maximum specified height $(6 \mathrm{~cm})$ for microgreens.

\section{Consumer acceptance of microgreens}

All microgreen species were evaluated for consumer acceptance using a 9-point hedonic scale (Lawless and Hayman, 2010); 9=like extremely and 1=dislike extremely where leaves of popularly consumed Asian pennywort (Centella asiatica) served as a control. Monoculture salads (single microgreen type with pepper, salt and lime juice) (Figure 1) were prepared and the species identities including the control were not divulged and the purpose of testing was not explained.
Phytochemical properties of seeds, sprouts and microgreens

For determination of antioxidant activity and total phenol content, three species of commonly consumed seeds (green peas, sesame, and finger millet) were selected. Batches of (3 to 5) dry seeds, sprouts (germinated in the incubator) and microgreens were dried at $38{ }^{\circ} \mathrm{C}$, ground, sieved $(0.5$ $\mathrm{mm}$ ) and extracted with $100 \%$ methanol (Sigma-Aldrich, MO,USA) on a mechanical shaker (2 days) and evaporated to a thick residue which was stored at $-18^{\circ} \mathrm{C}$. 2,2-Diphenyl picrylhydrazil (DPPH) (Sigma-Aldrich, MO, USA) radical scavenging antioxidant activity was determined (BrandWilliams, 1995) using DPPH (3 mL) and methanolic sample $(1 \mathrm{~mL})$ after incubating $(30 \mathrm{~min})$ in the dark. Absorbance was measured (UV-Visible spectrophotometer, Spec M02, Spectronic Camspec Ltd, UK) at $517 \mathrm{~nm}$ and for each sample $50 \%$ inhibitory concentration $\left(\mathrm{IC}_{50}\right)$ was calculated.

\section{Percentage Inhibition $=$ \\ $\underline{\text { (Absorbance of control-Absorbance of Sample) }} \times 100$ Absorbance of control}

The same methanolic extract was used to determine total phenols (ISO, 2005), Folin Ciacalteu reagent $(5.0 \mathrm{ml})$ (Loba Chemie, India) $(10 \% \mathrm{v} / \mathrm{v})$ was added to the aqueous sample (30\% methanol) $(1.0 \mathrm{~mL})$ and after mixing well (3-8 $\mathrm{min}), 7.5 \% \mathrm{Na}_{2} \mathrm{CO}_{3}(4.0 \mathrm{~mL})$ was added, and incubated (60 $\mathrm{min})$. Absorbance was measured at $765 \mathrm{~nm}$. Total phenolics were expressed as gallic acid (Sigma-Aldrich, MO, USA) equivalents per $100 \mathrm{~g}$ dry weight basis of the sample.
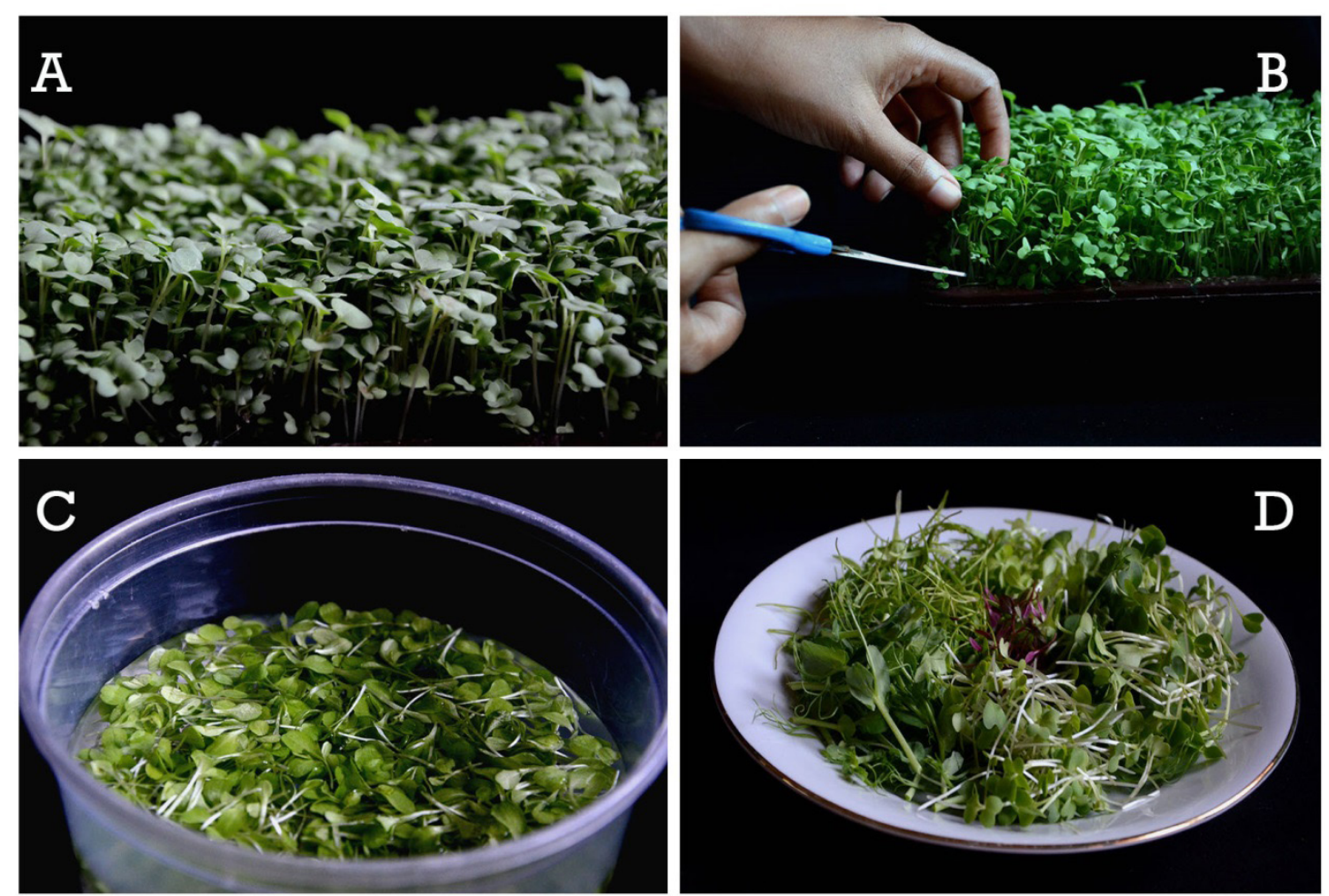

Figure 1: Steps involved in preparation of microgreen salads, A: microgreen at harvesting stage, B: harvesting microgreens, C: washing to remove plant debris and seed coat, D: Microgreen salad mix. 


\section{Experimental design and statistical analysis}

Germination tests were performed in four replicates (25 seeds per batch), the measurements of height and leaf area were obtained in 3 replicates (15 seedlings per replicate) using complete randomized design and all phytochemical analyses were conducted from three repeated trials for each sample. Percentage germination data were normalized by arcsine transformation prior to analysis. Consumer acceptance test was conducted involving 50 untrained volunteers between 22 - 50 years of age. Data were analyzed using t-tests for the comparison of two samples and oneway analysis of variance (ANOVA) when comparing more than two. The significance for all statistical analyses was set at $\mathrm{P}=0.05$.

\section{RESULTS AND DISCUSSION}

The absence of readily available, uniformly produced seeds was a constraint and we depended on seed stores meant for planting and food stores. Seeds meant for consumption did not give information on variety name, expiry dates, expected germination rates and chemical/ fungicide treatment, while all these data were available for the seeds meant for planting. As harvesting of microgreens commences at day 7 (Xiao et al., 2012) germination at day 7 was determined (Table 1).

The germination of sesame, green peas, finger millet, green peas and sesame slowed down significantly under total darkness (P values 0.002, 0.006 and 0.000 respectively) while light regime did not influence that of other seeds. Red amaranth showed poor germination $(<10 \%)$ irrespective of the light regime. The $\mathrm{G}_{75}$ values (Table 1) indicate that germination rates were fastest in fenugreek, green radish lettuce, mustard and sesame ( $<2$ days); moderate in Chinese kale and green peas (2-3 days); slow in carrot (7 days); very slow in finger millet and red amaranth ( $>14$ days). Among factors that attributed to poor germination are unfavourable temperature, quality and quantity of light, lack of moisture and inherent factors (Baskin and Baskin, 2014). High germination in Chinese kale, green radish and lettuce may indicate high seed vigor and seed coat treatments like fungicide applications as these are meant for planting. The finger millet seeds used were for human consumption. Their poor germination may be attributed to premature harvesting and they were susceptible to fungal attack despite disinfection. The red amaranth seeds were for cultivation and the label indicated $>80 \%$ germination. The difficulty of growing red amaranth seeds is mentioned by Lee and Pill (2005) and recommended seed priming and application of plant growth regulators to break dormancy.

Seedling emergence occurred within 4 days in most species, but carrot and red amaranth took 6 days, with time required to reach harvesting height ranging from $\sim 6$ to 14 days after sowing (Figure 2A). Green radish exceeded the maximum height limit $(6 \mathrm{~cm})$ within 6 days and true leaves emerged on day 8 . Lettuce, mustard, and sesame have shown moderate rates of growth and did not exceed the maximum height within 14 days, however true leaves emerged within 8-10 days. Chinese kale, green peas and fenugreek exceeded the specified height range within 8 days and true leaves emerged in the latter two on day 8. Carrot, finger millet, and red amaranth showed comparatively slow growth and exceeded the maximum height within 14 days, but true leaves emerged on day 16 and 14 in carrot and red amaranth respectively.

Table 1: Mean germination percentage and time taken to reach $75 \%$ germination $\left(\mathrm{G}_{75}\right)$ of 10 microgreens.

\begin{tabular}{|c|c|c|c|c|c|c|}
\hline \multirow{2}{*}{$\begin{array}{l}\text { Common } \\
\text { name }\end{array}$} & \multirow[b]{2}{*}{ Botanical name } & \multirow[b]{2}{*}{ Variety } & \multicolumn{2}{|c|}{$\begin{array}{l}\text { Mean germination } \\
\text { percentage after } 7 \text { days }\end{array}$} & \multirow{2}{*}{$\begin{array}{c}G_{75} \text { in light } / \\
\text { dark (12/12 } \\
\text { hrs) } \\
\text { (Days) }\end{array}$} & \multirow[b]{2}{*}{$\begin{array}{c}\text { Germination } \\
\text { type }\end{array}$} \\
\hline & & & $\begin{array}{c}\text { Total } \\
\text { darkness }\end{array}$ & $\begin{array}{c}\text { Light/Dark } \\
\text { (12 hrs/12 } \\
\text { hrs) }\end{array}$ & & \\
\hline Carrot* & Daucus carota & Kuroda & $75.0 \pm 3.8^{\mathrm{a}}$ & $79.0 \pm 4.4^{\mathrm{a}}$ & $6.5 \pm 0.4$ & epigeal \\
\hline Kale* & $\begin{array}{l}\text { Brassica oleracea var. } \\
\text { acephala }\end{array}$ & Chinese Kale & $95.0 \pm 1.9^{\mathrm{a}}$ & $94.0 \pm 1.2^{\mathrm{a}}$ & $2.7 \pm 0.2$ & epigeal \\
\hline Fenugreek & $\begin{array}{l}\text { Trigonella foenum- } \\
\text { graecum }\end{array}$ & $\mathrm{N} / \mathrm{A}$ & $94.0 \pm 1.9^{\mathrm{a}}$ & $98.0 \pm 1.2^{\mathrm{a}}$ & $1.5 \pm 0.1$ & epigeal \\
\hline Finger millet & Eleusine coracana & $\mathrm{N} / \mathrm{A}$ & $13.0 \pm 1.9^{\mathrm{b}}$ & $35.0 \pm 3.0^{\mathrm{a}}$ & $>14$ & hypogeal \\
\hline Green peas & Pisum sativum & N/A & $26.0 \pm 10.1^{\mathrm{b}}$ & $88.0 \pm 3.7^{\mathrm{a}}$ & $2.6 \pm 0.1$ & hypogeal \\
\hline $\begin{array}{l}\text { Green } \\
\text { radish* }\end{array}$ & Raphanus sativus & Japanese round & $98.0 \pm 1.2^{\mathrm{a}}$ & $98.0 \pm 1.2^{\mathrm{a}}$ & $0.9 \pm 0.0$ & epigeal \\
\hline Lettuce* & Lactuca sativa & Green coral & $93.0 \pm 2.0^{\mathrm{a}}$ & $93.0 \pm 1.2^{\mathrm{a}}$ & $1.1 \pm 0.3$ & epigeal \\
\hline Mustard & Brassica juncea & N/A & $88.0 \pm 1.2^{\mathrm{a}}$ & $86.0 \pm 2.5^{\mathrm{a}}$ & $1.4 \pm 0.6$ & epigeal \\
\hline Amaranth* & Amaranthussp. & Red Amaranth & $7.0 \pm 1.0^{\mathrm{a}}$ & $10.0 \pm 2.6^{\mathrm{a}}$ & $>14$ & epigeal \\
\hline Sesame & Sesamum indicum & $\mathrm{N} / \mathrm{A}$ & $2.0 \pm 1.2^{\mathrm{b}}$ & $92.0 \pm 1.6^{\mathrm{a}}$ & $1.9 \pm 0.1$ & epigeal \\
\hline
\end{tabular}

* Sign indicates fungicide treated seeds for growing purposes. Values are expressed as mean \pm standard error ( $\mathrm{n}=4)$. Different letters indicate a significant difference $(\mathrm{p}<0.05)$ within the same species.

$\mathrm{N} / \mathrm{A}$, variety names not available 

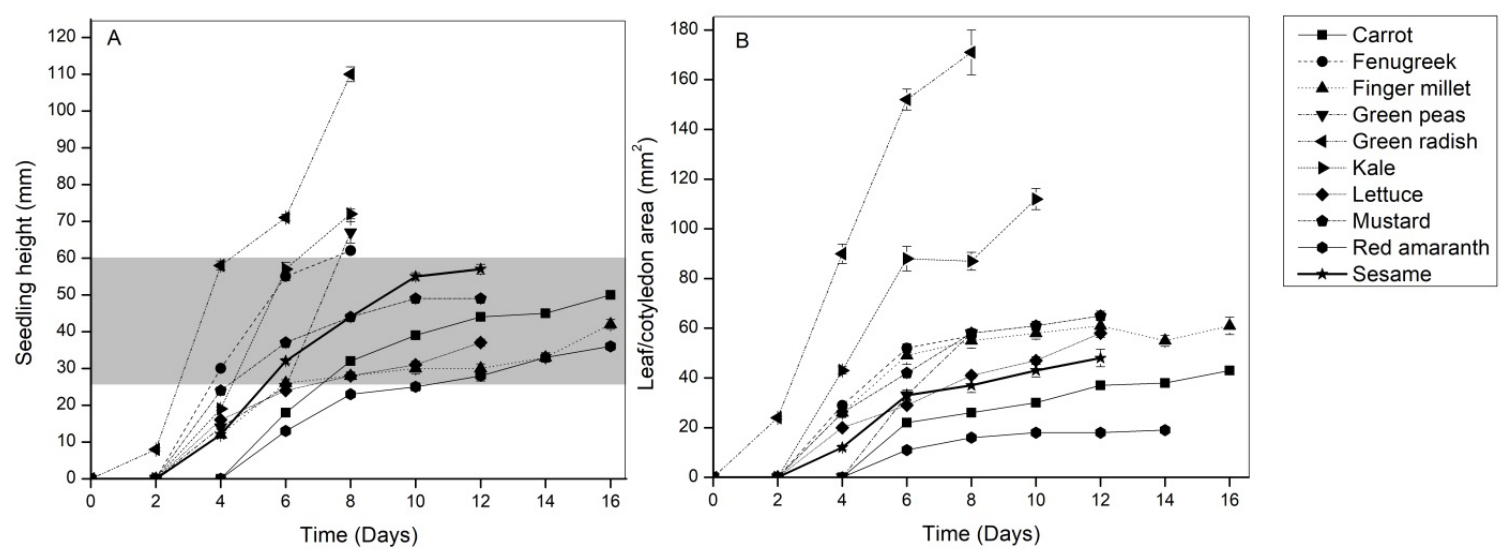

Figure 2: (A) Seedling height vs. time of harvest of seedlings of the ten species. The range highlighted in grey $(60-25 \mathrm{~mm})$ indicates acceptable height at harvest of microgreens; (B) Cotyledon or leaf area vs. time of harvest of seedlings of the ten species.

Green radish showed the highest cotyledon area followed by Chinese kale, while comparatively low values were exhibited by carrot, finger millet fenugreek, lettuce, mustard, red amaranth and sesame (Figure 2B). Even finger millet and green peas showed low rate of true leaf expansion (Figure 2B). In fenugreek, lettuce, mustard and sesame, rates of increase of cotyledon area appeared to decrease after true leaves emerged. The contribution of leaves in their role of functional foods is significant (Kopsell et al., 2012), hence having a larger leaf area is beneficial not only for the health of the growing plant but also for the nutrition and health of the consumer. While the definition for microgreens (Xiao et al., 2012) does not take the leaf area into account, in the present study, it was noted that there is a strong positive correlation between seedling height and leaf area, where $\mathrm{R}^{2}$ was 0.80 . Therefore, the usage of the height in the definition of microgreens which is more convenient than measuring leaf area is justified. Interestingly, days 6-8 are suitable for harvesting fenugreek, green peas, mustard, lettuce, and sesame based on their leaf areas which remain constant while their heights are still within the prescribed range. Considering the height and leaf area, 6-8 days is more suitable for harvesting green radish and Chinese kale. As finger millet did not show a considerable increase in height and leaf area after 16 days, harvesting can be between 12-16 days. Carrot and red amaranth did not exceed the maximum specified height even after 16 days but true leaves emerged between 14-16 days, which indicates that it is the suitable period for their harvesting.

Although, all the species were grown at $25^{\circ} \mathrm{C}$, ideally they will flourish at optimum temperature conditions. Cool season crops (kale, radish, carrots and lettuce) show optimum growth at $15-20{ }^{\circ} \mathrm{C}$. In spite of that, all plants have performed well at $25^{\circ} \mathrm{C}$ considering their $\mathrm{G}_{75}$ values, leaf area and height (Figure 2), which is encouraging as maintaining diverse conditions will incur higher production cost on the grower.

On sensory evaluation (Table 2), among the ten microgreen species, lettuce has received the highest preference (average hedonic value of 7.90 - like very much), while fenugreek and green radish have received least preference (average hedonic value of 3.90 and 3.72 respectively - dislike slightly). Lettuce and carrot can be considered as the most preferred microgreens along with Asian pennywort leaves (control). Green peas, red amaranth, and finger millet microgreens are next in the consumer preference followed by kale, sesame, and mustard. Since the panelists did not understand the concept of microgreens it was necessary to use lime juice, salt and pepper, to make them familiar to what they consume locally as leaf salads. Mustard is neither liked nor disliked and green radish is disliked slightly. Similarly, in a previous study (Xiao et al., 2015), Dijon mustard has received a generally intermediate score and Chinese rose radish received a low score in overall eating quality. While red amaranth is liked slightly in the present study, it is reported to have a higher rank (Xiao et al., 2015) due to its appealing red colour and acceptable flavour. The acceptability based on organoleptics is heavily dependent on acquired attributes and this may be an important consideration in the initial stages of commercializing microgreens. Ironically, unacceptable flavours such as bitterness may be due to various biochemicals which may be beneficial for health. Radish and mustard are known to be rich in glucosinolates which are bitter (Drewnowski and Gomez-Carneros, 2000) and phenolics generally contribute to a not so appealing astringent flavour (Tomás-Barberán and Espín, 2001).

With appropriate education of the consumer of the benefits of microgreens, their acceptance may increase despite not so superior taste attributes. The control, Asian pennywort, although its identity was not revealed, was recognized by all panelists by the taste. Despite its familiarity and popularity, it was only liked moderately (Table 2). This is an observation that not so superior taste attributes will get underplayed in consumer acceptance if the health benefits are known. As microgreens are consumed in mixed salads, the consumer can incorporate many varieties in combined salads giving vivid colour, flavor, texture and odour. Reducing the proportions of the 
Table 2: Consumer acceptance rating of ten microgreens.

\begin{tabular}{llll}
\hline \multicolumn{1}{c}{ Microgreen species } & \multicolumn{1}{c}{$\begin{array}{c}\text { Mean hedonic } \\
\text { acceptance value }\end{array}$} & \multicolumn{1}{c}{$\begin{array}{c}\text { Hedonic scale } \\
\text { description }\end{array}$} & \multicolumn{1}{c}{$\begin{array}{c}\text { Special comments of } \\
\text { panelists }\end{array}$} \\
\hline Asian pennywort (control) & $7.14^{\mathrm{a}}$ & Like moderately & - \\
\hline Carrot & $7.30^{\mathrm{a}}$ & Like moderately & Savoury flavour \\
\hline Chinese kale & $4.90^{\mathrm{c}}$ & neither like nor dislike & - \\
\hline Fenugreek & $3.90^{\mathrm{d}}$ & dislike slightly & $\begin{array}{l}\text { Strong bitter taste, } \\
\text { prolonged after taste }\end{array}$ \\
\hline Finger millet & $6.14^{\mathrm{b}}$ & Like slightly & Earthy/grassy mouth feel \\
\hline Green peas & $6.42^{\mathrm{ab}}$ & Like slightly & - \\
\hline Green Radish (Japanese round) & $3.72^{\mathrm{d}}$ & dislike slightly & Unpleasant odour \\
\hline Lettuce (Green coral) & $7.90^{\mathrm{a}}$ & Like very much & Savoury, crunchy flavour \\
\hline Mustard & $4.70^{\mathrm{cd}}$ & neither like nor dislike & - \\
\hline Red amaranth & $6.16^{\mathrm{b}}$ & Like slightly & - \\
\hline Sesame & $4.74^{\mathrm{c}}$ & neither like nor dislike & Slight bitter taste \\
\hline
\end{tabular}

Different letters indicate a significant difference $(\mathrm{p}<0.05)$ in different species compared to the control.

Table 3: DPPH (Diphenyl pycrylhydrazil) radical scavenging antioxidant activity expressed as (50\% Inhibitory concentration) and total phenols content and moisture content of the selected three species of which seeds are consumed popularly in Sri Lanka.

\begin{tabular}{|c|c|c|c|c|c|c|c|c|c|}
\hline \multirow[t]{2}{*}{ Species } & \multicolumn{3}{|c|}{$\begin{array}{c}\text { DPPH Antioxidant activity } \mathrm{IC}_{50} \\
\qquad(\mu \mathrm{g} / \mathrm{mL})\end{array}$} & \multicolumn{3}{|c|}{$\begin{array}{l}\text { Total phenols (Gallic acid } \\
\text { equivalents of } \mathrm{mg} / 100 \mathrm{~g} \text { dry } \\
\text { weight) }\end{array}$} & \multicolumn{3}{|c|}{ Moisture Content (\%) } \\
\hline & Seed & Sprout & Microgreen & Seed & Sprout & Microgreen & Seed & Sprout & Microgreen \\
\hline Finger millet & $697 \pm 13^{c}$ & $3037 \pm 269^{b}$ & $4339 \pm 86^{a}$ & $709 \pm 13^{a}$ & $182 \pm 10^{c}$ & $324 \pm 10^{\mathrm{b}}$ & 33.3 & 63.4 & 90.5 \\
\hline Green peas & $5237 \pm 31^{\mathrm{a}}$ & $2519 \pm 99^{b}$ & $1830 \pm 109^{c}$ & $469 \pm 3^{c}$ & $686 \pm 2^{b}$ & $1871 \pm 64^{a}$ & 22.8 & 59.4 & 75.3 \\
\hline Sesame & $3149 \pm 44^{a}$ & $895 \pm 38^{b}$ & $772 \pm 32^{c}$ & $120 \pm 1^{\mathrm{b}}$ & $335 \pm 15^{b}$ & $4873 \pm 87^{\mathrm{a}}$ & 25.0 & 72.1 & 92.8 \\
\hline
\end{tabular}

All values are expressed as mean \pm standard error $(n=3)$. Different letters indicate a significant difference $(p<0.05)$ within the same species.

not so acceptable species in the salad mixture is another way to gain health benefits without compromising the taste.

Of the ten species, three popularly consumed seeds were singled out to analyse antioxidants at three stages; seeds, sprouts, and microgreens. Absence of fungicide or chemical treatments, and not being investigated before in other studies, as microgreens are other criteria to choose these three. The microgreens of green peas and sesame show the highest antioxidant activity (based on lower $\mathrm{IC}_{50}$ ) as compared to respective seeds and sprouts (Table 3). Health beneficial substances may be formed in diverse ways depending on the species during growth from seed to sprout to microgreens. Therefore, future studies should aim at determining relative levels of such substances with time of germination. The sesame microgreens exceeded total phenol content (4873 mg GA equivalents/100 g dry weight) when compared to all seeds, sprouts and microgreens. Additionally, in sesame, $\mathrm{IC}_{50}$ decreased from seed to microgreen production indicating that the best method of consuming sesame is as microgreens.

Also, despite its hypogeal germination, green pea microgreens show higher antioxidant activity and higher total phenol value. Finger millet, the other hypogeal germinating seed tested, showed a decrease in total phenols from seeds to sprouts, and again an increase from sprouts to microgreens with seeds showing the highest levels. Finger millet seeds also recorded a lower $\mathrm{IC}_{50}$ value showing that the best way to consume them is as seeds. The presence of carotenoids, tocopherol and phenolic compounds such as luteolin in finger millet seeds result in high antioxidant activity (Mathanghi and Sudha, 2012). The seed coat of green peas is rich in phenolic compounds such as glycosides of quercetin, luteolin and apigenin and the cotyledons are known to be rich in hydroxyl benzoic acid and hydroxyl cinnamic acid (Duenas et al., 2004).

As different parts of the plants such as seeds, cotyledons and leaves may have different health promoting properties, the ideal time of consumption to benefit by their phytochemicals vary, which shows the importance of determining antioxidant activity at different stages. Seed germination is known to increase the levels of nutrients such as antioxidants and reduce the levels of antinutrients such as phytic acids (Seneviratne et al., 2012). Also, in spite of the fact that the microgreen market concentrates on seeds with epigeal germination, 
the positive results obtained for microgreens of peas in the present study is a cue to test for other seeds with hypogeal germination as microgreens. To start a lucrative business in microgreens, it is important to have a ready supply of seeds with high viability, fast germination and free of agrochemicals.

\section{CONCLUSION}

With the simple setup used, it was possible to grow microgreens satisfactorily. Use of seedling height as a harvesting index can be recommended, as it can be determined easily. However, results from the study showed that leaf area can also be used as a harvesting stage index. As green pea microgreens showed higher total phenol content than its seeds, the advantage of using microgreens from hypogeal germinated species too should be determined. Microgreen consumption should be popularized by educating the consumers of their benefits, as taste alone is not a good criterion to judge the health promoting properties. As the highest antioxidant activity was shown by finger millet seeds, rather than its sprouts or microgreens, it is not possible to assume that microgreens of any species are healthier than the seeds. Therefore more information is required on species that are suitable to be developed as microgreens rather than consuming as seeds alone.

\section{Conflicts of interest}

The authors declare that they have no conflicts of interest pertaining to this study.

\section{REFERENCES}

Baskin, C. C. and Baskin, J. M. (2014). Seeds: ecology, biogeography, and evolution of dormancy and germination. ( $2^{\text {nd }}$ ed.). Elsevier.

Brand-Williams, W., Cuvelier, M.E. and Berset, C. (1995). Use of a free radical method to evaluate antioxidant activity. Lebensmittel Wisseenchaft Technologie 28: 2530.

Duenas, M., Estrella, I. and Hernandez, T. (2004). Occurrence of phenolic compounds in the seed coat and the cotyledon of peas (Pisum sativum L.). European Food Research Technology 219: 116-123.

Drewnowski, A. and Gomez-Carneros, C., (2000). Bitter taste, phytonutrients, and the consumer: a review. American Journal of Clinical Nutrition 72: 1424-1435.

Ebert, A. (2012). Sprouts, microgreens, and edible flowers: the potential for high value specialty produce in Asia. Proceedings SEAVEG2012 Regional Symposium, Chiang Mai, Thailand, Pp. 216-227.

ISO (2005).Content of total polyphenols in tea-colorimetric method using folinciocalteu reagent-international standards-ISO 14502-1.

Kopsell, D.A., Pantanizopoulos, N.I., Sams, C.E. and Kopsell, D.E. (2012). Shoot tissue pigment levels increase in 'Florida Broadleaf' mustard (Brassica juncea L.) microgreens following high light treatment. Scientia Horticulturae 140: 96-99.

Lawless, H.T. and Heyman, H. Sensory Evaluation of Food. (2 ${ }^{\text {nd }}$ ed.) Springer, New York. (Chapter 14).
Lee, J.S. and Pill, W.G. (2005).Advancing greenhouse establishment of radish, kale, and amaranth microgreens through seed treatments. Horticulture Environment and Biotechnology 46: 363-368.

Mathanghi, S.K. and Sudha, K. (2012). A review: Functional and phytochemical properties of finger millet (Eleusine coracana L.) for health. International Journal of Pharmaceutical, Chemical and Biological Sciences 2: 421-438.

Mir, S.A., Shah, M.A. and Mir, M.M. (2017). Microgreens: Production, shelf life, and bioactive components. Critical Reviews in Food Science and Nutrition, 57, 2730-2736.

Seneviratne, M., Gunasinghe, W.K.R., Gama-Arachchige, N.S., Dissanayake, N. and Karunaratne, A. (2012). Mineral bioavailability in three locally consumed pulses processed using popular methods: interpreted using molar ratios with phytic acid. Ceylon Journal of Science (Biological Sciences) 41: 19-26.

Tomás-Barberán, F. and Espín, J.C. (2001). Phenolic compounds and related enzymes as determinants of quality in fruits and vegetables. Journal of Science of Food and Agriculture 81: 853-876.

Treadwell, D. D., Hochmuth, R., Landrum, L. and Laughlin, W. (2010). Microgreens: a new specialty crop. Institute of Food and Agriculture Sciences, University of Florida. (UF/IFAS Extension Service). http://edis.ifas.ufl.edu/ hs1164 / (16.01.2017).

World Health Organization. (2017). The 10 leading causes of death in the world, 2000 and 2012.http://www.who. int/mediacentre/factsheets/fs310/en/(02.02.2018)

Xiao, Z., Lester, G.E., Luo, Y. and Wang, Q. (2012). Assessment of vitamin and carotenoid concentrations of emerging food products: edible microgreens. Journal of Agricultural and Food Chemistry 60: 7644-7651.

Xiao, Z., Lester, G.E., Park, E., Saftner, R.A., Lou, Y. and Wang, Q. (2015). Evaluation and correlation of sensory attributes and chemical compositions of emerging fresh produce: microgreens. Postharvest Biology and Technology 110: 140-148.

Xiao, Z., Codling, E.E., Luo, Y., Nou, X., Lester, G.E. and Wang, Q. (2016). Microgreens of Brassicaceae: Mineral composition and content of 30 varieties. Journal of Food Composition and Analysis 49: 87-93. 